|| ISSN(online): 2589-8698 || ISSN(print): 2589-868X ||

International Journal of Medical and Biomedical Studies

Available Online at www.ijmbs.info

NLM (National Library of Medicine ID: 101738825)

Index Copernicus Value 2019: 79.34

Original Research Article

Volume 5, Issue 4; April: 2021; Page No. 108-109

\title{
LIPID PROFILE ABNORMALITIES IN NEPHROTIC SYNDROME
}

\author{
Dr. Darshna Jain, ${ }^{1}$ Dr. Anurag Kesarwani ${ }^{2}$, Dr. Deepasha Shahi Bagzai ${ }^{3}$ \\ ${ }^{1}$ Assistant Professor, Biochemistry, Government Medical College Ratlam(MP) \\ ${ }^{2}$ Assistant Professor, Biochemistry, Government Medical College Shahdol (MP) \\ ${ }^{3}$ Assistant Professor, Biochemistry, MGM Medical College Indore (MP)
}

Article Info: Received 29 February 2021; Accepted 19 April 2021

DOI: https://doi.org/10.32553/ijmbs.v5i4.1874

Corresponding author: Dr. Anurag Kesarwani

Conflict of interest: No conflict of interest.

Abstract

Background: Nephrotic syndrome common disease in children. To study the lipid profile in nephrotic syndrome.

Methods: This is a case-control study in which 100 Normal patients and 100 patients. The Serum lipid profiles of the patients were evaluated.

Results: There was a significant increase in Total cholesterol, HDL, LDL, VLDC \& TG in Nephrotic patients when compared to Controls. The study finding conclude that the serum lipid profile shoed noticeable increase in the nephrotic syndrome in Indian patients.

Conclusion: We concluded that nephrotic patients are having hyperlipidaemia. This hyperlipidaemia may progress in to the cardiovascular diseases. Hence the lipid profile in the nephrotic syndrome must be monitored for better management of the diseases.

Keywords: Lipid profile, Nephrotic syndrome, Hyperlipidemia

\section{Introduction:}

Nephrotic syndrome is usually accompanied by retention of water and sodium. The degree to which this occurs can vary between slight edema in the eyelids that decrease during the day, to affecting the lower limbs, to generalized swelling, to full-blown anasarca. ${ }^{2}$

Nephrotic syndrome is caused by different disorders that damage the kidneys. This damage leads to the release of too much protein in the urine. Common primary causes of nephrotic syndrome include kidney diseases such as minimal-change nephropathy, membranous nephropathy, and focal glomerulosclerosis. Secondary causes include systemic diseases such as diabetes mellitus, lupus erythematosus, and amyloidosis. Congenital and hereditary focal glomerulosclerosis may result from mutations of genes that code for podocyte proteins, including nephrin, podocin, or the cation channel 6 protein. Nephrotic syndrome can result from drugs of abuse, such as heroin. ${ }^{2}$

Nephrotic syndrome is usually accompanied by retention of water and sodium. The degree to which this occurs can vary between slight edema in the eyelids that decreases during the day, to affecting the lower limbs, to generalized swelling, to full blown anasarca. ${ }^{3}$

Nephrotic syndrome is characterized by large proteinuria (>3.5 g per $1.73 \mathrm{~m} 2$ body surface area per day, ${ }^{3}$ or $>40 \mathrm{mg}$ per square meter body surface area per hour in children), hypoalbuminemia $(<2,5 \mathrm{~g} / \mathrm{dl})$, hyperlipidaemia, and edema (which is generalized and also known as anasarca or dropsy) that begins in the face. Lipiduria (lipids in urine) can also occur, but is not essential for the diagnosis of nephrotic syndrome. Hyponatremia also occurs with a low fractional sodium excretion. ${ }^{4}$

Hyperlipidaemia is caused by two factors: 1 Hypoproteinemia stimulates protein synthesis in the liver, resulting in the overproduction of lipoproteins. 2 Lipid catabolism is decreased due to lower levels of lipoprotein lipase, the main enzyme involved in lipoprotein breakdown. ${ }^{5}$ Cofactors, such as apolipoprotein $\mathrm{C} 2$ may also be lost by increased filtration of proteins.

\section{Material and Methods}

Type of study-Case control study

Sampling methods- Simple random sampling

Study included 100 cases of children with nephrotic syndrome for this prospective study. 100 children without liver and kidney disorders were taken as control group. 100 nephrotic syndrome cases were clinically examined and following investigations were performed in each case, before steroid therapy (ISKDC Regimen), after one month of steroid therapy and at the end of therapy.

Inclusion Criteria:

- All infants and children between 0-12 years of age suffering from nephrotic syndrome.

Exclusion Criteria:

- Children with liver disorders.

- Children with oedema due to Kwashiorkor

- Children with oedema due to $\mathrm{CCF}$ 
- Children suffering from kidney diseases other than nephrotic syndrome.

Pre-structured proforma was used to record the information from the individual. After getting the consent from the parents clinical data were collected and entered in the proforma, which include age, sex, presenting complaints, drug history and type of nephrotic syndrome.

After history taking and clinical examination, blood samples were collected from the patients for lipid profile and thyroid function. The enzymaticmethod used for measurement of serum cholesterol and VLDL, the enzymatic calorimetric method used for measurement of LDL and triglycerides, phosphotungstate method for HDL and photometric method used for measuring serum albumin.

Data analysis:

For categorical variable chi-square test was used. $\mathrm{P}$ value of $<0.05$ consider as significant.

\section{Results}

The 100 Normal patients \& 100 Nephrotic syndrome patients were studied.

Table 1: Socio-demographic profile

\begin{tabular}{|l|l|l|l|}
\hline Variable & Control & Cases & p-value \\
\hline Age & $9.61 \pm 2.27$ & $9.35 \pm 2.46$ & $>0.05$ \\
\hline Male : Female & $63: 37$ & $67: 33$ & $>0.05$ \\
\hline
\end{tabular}

Both group were comparable.

Table 2: Observed Serum Levels of lipo proteins

\begin{tabular}{|l|l|l|l|}
\hline Lipid profile & Control & Cases & p-value \\
\hline $\begin{array}{l}\text { Total Cholesterol } \\
(\mathrm{mg} / \mathrm{dl})\end{array}$ & $174.23 \pm 27.09$ & $320.12 \pm 102.56$ & $<0.05$ \\
\hline $\begin{array}{l}\text { High Density } \\
\text { Lipids (mg/dl) }\end{array}$ & $45.16 \pm 6.3$ & $102.36 \pm 8.69$ & $<0.05$ \\
\hline $\begin{array}{l}\text { Low Density } \\
\text { Lipids (mg/dl) }\end{array}$ & $123.64 \pm 20.14$ & $180.09 \pm 40.09$ &,$<0.05$ \\
\hline $\begin{array}{l}\text { Triglycerides } \\
(\mathrm{mg} / \mathrm{dl})\end{array}$ & $90.56 \pm 15.24$ & $170.80 \pm 20.12$ & $<0.05$ \\
\hline
\end{tabular}

\section{Discussion}

The above data showed significant increase level of the lipo proteins. The level of the cholesterol, HDL, LDL \& triglycerides is founds to be markedly increases. This concludes that hypercholesterolemia in the nephrotic patients. The hypercholesterolemia is observed is also previously reported in nephrotic syndrome study Krishnaswany D et al, Appel G.B. et al and Alexander J.H et al showed the same findings. ${ }^{5-7}$

The level of the HDL decrease is also reported in previous studies. Adekoya A.O showed the same results of the decrease in levels of the $\mathrm{HDL}^{8}$
The increased LDL can be explained by severe reduction of hepatic LDL receptor protein abundance in nephrotics despite normal LDL receptor mRNA abundance and gene translation rate. ${ }^{9}$

\section{Conclusion:}

The study finding concludes that the serum lipid profile showed noticeable increase in the nephrotic syndrome. It also observed that nephrotic patients are having hyperlipidemia. This hyperlipidemia may progress into the cardiovascular diseases. Hence the lipid profile in the nephrotic syndrome must be monitored for better management of the diseases.

\section{References:}

1. Afroz S, Khan AH, Roy DK. Thyroid function in children with nephrotic syndrome. Mymensingh Med J. 2011;20(3):407-11

2. Bhandari, Mandowara SL. Lipoprotein profile in nephrotic syndrome. Indian Pediatr. 1980;17:416-9.

3. Carrie BJ, Salyer WR, Myers BD. Minimal change nephropathy: an electrochemical disorder of the glomerular membrane. Am J Med. 1981;70:262.

4. Clark AG, Barratt TM. Steroid-responsive nephrotic syndrome. In: Barratt TM, Avner ED, Harmon, eds. Pediatric Nephrology. Baltimore: Lippincott, Williams \& Wilkins; 1998:731-4

5. Krishnaswany D , Indumati V , Satihkumar D ,Viijay V, Maharudra S , Amareshwara M and Rajeshwari V. Serum proteins, initial and follow-up lipid profile in children with nephrotic syndrome. IJABPT $2011 ; 2: 59-63$.

6. Appel G.B, Blum C.B, Chein S, Kunis C.L and Appel A.S. The hyperlipideamia of the nephrotic syndrome: relation to plasma albumin concentration, oncotic pressure, and viscosity. $\mathrm{N}$ Engl $\mathrm{J}$ Med1985;312:1544-1548.

7. Alexander J.H, Schapel G.J and Edwards K.D. Increased incidence of coronary heart disease associated with combined elevation of serum triglycerides and cholesterol concentrations in the nephrotic syndrome in man. Med J Aust 1974; 2:119-122.

8. Adekoya A.O, Adekoya B.J, Desalu O.O and Aderibigbe A. Pattern of lipid profile in adult nephrotic syndrome patients in Nigeria. Int $\mathrm{J}$ Bio Med Res 2011;2:954-960.

9. Warwick G.L, Packard C.J, Demant T, Beedford D.C, Bunlton J.M and Shepherd J. Metabolism of apolipoprotein B-containing lipoproteins in subjects with nephrotic range protienuria. Kidney Int 1991;40:129-138. 